\title{
BRAMA DO WIEDZY. ROLA BIBLIOTEKI AKADEMICKIEJ W PROCESIE KOMUNIKACJI NAUKOWEJ NA PRZYKŁADZIE BIBLIOTEK AKADEMICKICH W LODZI
}

\begin{abstract}
Academic libraries are an important link in the process of scientific communication. In carrying out assigned tasks for the university environment, they need to adjust their offer to changing conditions of the modern science. The roles of academic libraries also undergo changes. The article presents a catalog of functions of these institutions. Issues related to scientific communication are the background for these considerations. The roles of academic libraries are discussed on the example of the Library of the University of Lodz.
\end{abstract}

Słowa kluczowe: komunikacja naukowa, biblioteki akademickie, usługi biblioteczne, open access

\section{Wstęp}

Biblioteka od zawsze była istotnym miejscem dla środowiska naukowego, wspierała naukowców w ich działaniach, oferowała bogaty warsztat pracy, pośredniczyła $\mathrm{w}$ kontaktach międzyuczelnianych. Biorąc pod uwagę zmiany, jakie zaszły i nadal zachodzą za sprawą nowych technologii w komunikacji naukowej, instytucje wspierające ten proces powinny znaleźć dla siebie odpowiednie role, często nowe i odmienne od tych pełnionych tradycyjnie.

Transformacje procesów publikowania inicjują wydawcy i sami autorzy. Uczelnie reagują na zachodzące przemiany, na przykład tworząc nowe jednostki międzywydziałowe (takie jak działy nauki czy centra transferu technologii). Biblioteki naukowe również szukają sposobów na efektywne wspieranie procesu komunikacji naukowej i oferują badaczom pomoc związaną z różnymi aspektami ich pracy. W niniejszym artykule poruszone zostaną kwestie pełnienia przez biblioteki naukowe ról tradycyjnie im przypisanych, jak i podejmowania się przez nie nowych zadań w aspekcie ewolucji systemu komunikacji naukowej. Zaprezentowane wyniki badań z Łodzi pokazują, jak współczesne biblioteki akademickie pracują dla środowiska naukowego uczelni. 


\section{Komunikacja naukowa}

Proces tworzenia wiedzy jest zjawiskiem społecznym i zachodzi w dużej mierze dzięki stałym interakcjom - komunikacji i współpracy ${ }^{1}$. Komunikacja naukowa to przede wszystkim informowanie o wynikach badan naukowych i popularyzowanie ich. Proces powinien zachodzić dwutorowo i trafiać do dwóch różnych grup odbiorców: do naukowców (akumulacja wiedzy) oraz do ogółu społeczeństwa (popularyzowanie nauki). Komunikacja naukowa może odbywać się w sposób formalny (na przykład publikowanie wyników badań w czasopismach) lub nieformalny (teksty publikowane na prywatnych stronach, blogach, w mediach społecznościowych, dyskusje online, prywatna komunikacja) ${ }^{2}$.

Komunikacja naukowa nie ulegała znaczącym zmianom od XVII w. aż do lat sześćdziesiątych XX w., kiedy część procesu komunikacji zaczęto przenosić do sieci internetowej, a do systemu dołączyły prywatne firmy - wydawcy i dostawcy treści naukowych ${ }^{3}$. Na rozwój systemu znaczący wpływ miało pojawienie się licznych sposobów publikowania w formie elektronicznej, w tym samopublikowania, a także idące za tym możliwości korzystania z naukowych zasobów cyfrowych z każdego miejsca na świecie, o dowolnej porze. „Komunikacja naukowa jako część procesu naukowego uległa istotnym zmianom wraz z upowszechnieniem się Internetu"4, a obecnie nowe sposoby wymiany myśli są z powodzeniem używane równolegle do tych, które można uznać za tradycyjne.

Warto zwrócić uwagę, że komunikacja naukowa wciąż przystosowuje się do funkcjonowania $w$ nowym środowisku sieciowym, które jest bardzo zmienne. W latach dziewięćdziesiątych zainicjowano ruch Open Access (OA), który spowodował powrót do idei przyświecających nauce od samego jej początku. Pojawiające się postulaty otwartości i szerokiego dostępu do wyników badań naukowych początkowo miały związek z aspektami finansowymi (podwójne finansowanie) $)^{5}$. W 2012 r. rozpoczęła się tak zwana akademicka wiosna ${ }^{6}$. Władze Biblioteki Harvardzkiej wystosowały list do naukowców o coraz droższych prenumeratach czasopism i zaapelowały o publikowanie artykułów w modelu

${ }^{1} \mathrm{~F}$. Barjak, The Role of the Internet in Informal Scholarly Communication, „Journal of the American Society for Information Science and Technology" 2006, nr 57 (10), s. 1350-1367.

${ }^{2}$ M. Carpenter, J. Graybill, J. Offord Jr., M. Piorun, Envisioning the Library's Role in Scholarly Communication in the Year 2025. „Portal: Libraries and the Academy” 2011, nr 11 (2), s. 659.

${ }^{3}$ D.E. Shulenburger, Scholarly Communications Is Not Toxic Waste: Lessons Learned, 2004, [dostęp: 1.07.2015], http://kuscholarworks.ku.edu/dspace/handle/1808/58.

${ }^{4}$ E. Kulczycki, Blogi i serwisy naukowe. Komunikacja naukowa w kulturze konwergencji, 2006, [dostęp: 1.07.2015], https://www.repozytorium.amu.edu.pl/jspui/handle/10593/2520.

${ }^{5}$ E. Bendyk, Przewodnik po otwartej nauce. Warszawa 2009, s. 16-22.

${ }^{6}$ A. Hołdys, Harvard Buntuje Naukowców, „Gazeta Wyborcza”, 2012, [dostęp: 1.07.2015], http://wyborcza.pl/1,75476,11736662,Harvard_buntuje_naukowcow.html. 
Open Access ${ }^{7}$. W trwającym dyskursie aspekty ekonomiczne nadal są niezwykle istotne, ale badane są również inne przejawy otwierania nauki i zmian zachodzących w procesie komunikacji naukowej.

\section{Biblioteka akademicka w komunikacji naukowej}

Główne zadania bibliotek to: „1) gromadzenie, opracowywanie, przechowywanie i ochrona materiałów bibliotecznych; 2) obsługa użytkowników, przede wszystkim udostępnianie zbiorów oraz prowadzenie działalności informacyjnej"8. Biblioteka akademicka funkcjonując w środowisku naukowym angażuje się we wspieranie procesu komunikacji naukowej w różnym zakresie - cele swojej działalności poszczególne instytucje wpisują w statucie oraz w swoją misję.

Bardzo ważne jest to, jak biblioteka będzie kształtowała swoją ofertę dla środowiska akademickiego. Zmiany, które zaszły i nadal zachodzą za sprawą ewolucji systemów komunikacji i rozwoju technologii, wymuszają wytyczenie nowych kierunków rozwoju. Wymaga się, aby oferta biblioteki akademickiej spełniała potrzeby zróżnicowanego środowiska naukowego, w którym są zarówno tradycjonaliści, przywiązani do dawnych metod pracy ze źródłami naukowymi, jak i badacze w pełni korzystający z dobrodziejstw systemów elektronicznych ${ }^{9}$. Wyznaczając nowe pola działania biblioteka powinna zachować poszanowanie dla swojej tradycji. Wymaga to głębokiego zastanowienia nad przyszłością i wyobrażenia sobie nowych dróg rozwoju ${ }^{10}$.

W literaturze przedmiotu można znaleźć tradycyjne role przypisane bibliotece w komunikacji naukowej. Są to:

- organizowanie i zapewnianie dostępu do zbiorów (w tym do zasobów elektronicznych);

- $\quad$ pomoc w wyszukiwaniu wiarygodnych źródeł informacji dla naukowców;

- $\quad$ przygotowywanie raportów cytowań;

- $\quad$ gromadzenie i archiwizowanie prac powstałych w macierzystej uczelni.

Badacze zajmujący się tematyką bibliotek akademickich wskazują też na nowe role, które biblioteki zaczęły już pełnić lub które pełnić dopiero zaczną ${ }^{11}$.

${ }^{7}$ I. Sample, Harvard University Says It Can't Afford Journal Publishers Prices. „The Guardian", 2012 nr 24, [dostęp: 1.07.2015], http://wyborcza.pl/1,75476,11736662,Harvard_ buntuje_naukowcow.html.

${ }^{8}$ Ustawa z dnia 27 czerwca 1997 r. o bibliotekach, „Dziennik Ustaw” 1997, nr 85 , poz. 539 , art. 4.

${ }^{9}$ K. Guthrie, R. Housewright, Repackaging the Library: What Do Faculty Think? „Journal of Library Administration” 2010, nr 51 (1), s. 91.

${ }^{10}$ G. Delaney, Geraldine, J. Bates, Envisioning the Academic Library: A Reflection on Roles, Relevancy and Relationships, „New Review of Academic Librarianship”, 2014, [dostęp: 1.07.2015], http://dx.doi.org/10.1080/13614533.2014.911194.

${ }^{11}$ M. Carpenter, J. Graybill, J. Offord Jr., M. Piorun, Envisioning the Library's Role in Scholarly Communication in the Year 2025, „Portal: Libraries and the Academy” 2011, nr 11 (2), s. 659-81. 
Do nietradycyjnych funkcji pełnionych przez biblioteki naukowe i wyzwań przed nimi stojących można zaliczyć ${ }^{12,13}$ :

- promowanie Open Access;

- $\quad$ większe wspieranie samego procesu publikowania prac naukowych;

- $\quad$ edukacja informacyjna;

- $\quad$ tworzenie standardów, wytycznych, rekomendacji, a nawet nowych narzędzi dla naukowców.

\section{Rola biblioteki akademickiej w komunikacji naukowej na przykładzie lódzkich książnic akademickich}

Przyjmowanie nowych ról wymaga od bibliotek dużego zaangażowania oraz znalezienia sojuszników. W tym rozdziale artykułu zaprezentowane zostaną wyniki badań własnych. Podczas wywiadów przeprowadzonych $\mathrm{z}$ dyrektorami czterech największych bibliotek akademickich Łodzi, sprawdzono jak książnice wspierały proces komunikacji naukowej w swoich uczelniach. Wywiady przeprowadzono w maju 2015 r., celem badań było określenie stopnia zaangażowania bibliotek oraz sprawdzenie i zestawienie ich działalności związanej ze wspieraniem komunikacji naukowej. W badaniu udział wzięli:

- mgr Hanna Bort-Nowak, dyrektor Biblioteki Akademii Sztuk Pięknych w Łodzi (BASP);

- $\quad$ mgr inż. Błażej Feret, dyrektor Biblioteki Politechniki Łódzkiej (BPŁ);

- $\quad$ mgr inż. Witold Kozakiewicz, zastępca dyrektora ds. komputeryzacji Biblioteki Uniwersytetu Medycznego w Łodzi (BG UMED);

- $\quad$ mgr Tomasz Piestrzyński, dyrektor Biblioteki Uniwersytetu Łódzkiego (BUŁ).

Wszyscy dyrektorzy uznali, że wspieranie procesu komunikacji naukowej jest bardzo istotnym zadaniem. Piestrzyński wskazał, że środowisko naukowe uczelni to jeden z najważniejszych odbiorców działań bibliotek akademickich, stąd podejmowanie działań dla tej grupy zostało potraktowane priorytetowo. Według Fereta rola ta była tradycyjnie bardzo silna w bibliotekach, a obecnie odnotowano jej spadek ze względu na rosnącą samodzielność naukowców i możliwość korzystania z zasobów naukowych bez wychodzenia z miejsca pracy czy domu - coraz częściej pracownicy uczelni mają możliwość pozyskania potrzebnych informacje pozainstytucjonalnie. Kozakiewicz uważał, że biblioteka spełniała rolę pomocniczą, wspierającą, a ważny jej element

\footnotetext{
${ }^{12}$ Ibidem.

${ }^{13}$ J. Gelfand, C. Palmer, Weaving Scholarly Communication and Information Literacy: Strategies for Incorporating Both Threads in Academic Library Outreach, [w:] Common Ground at the Nexus of Information Literacy and Scholarly Communication, Chicago 2013, s. 1-24, [dostęp: 1.07.2015], http://www.ala.org/acrl/sites/ala.org.acrl/files/content/publications/booksand digitalresources/digital/commonground_oa.pdf.
} 
stanowiło także doradztwo. Bort-Nowak wskazała na specyfikę uczelni artystycznej - funkcjonowanie biblioteki w takim ośrodku zobowiązywało do większej otwartości i podejmowania się realizacji zadań tradycyjnych i nietradycyjnych.

\section{Tradycyjne role pełnione przez lódzkie biblioteki akademickie}

Tradycyjną rolą, realizowaną w bardzo szerokim zakresie przez wszystkie badane biblioteki, jest organizowanie i zapewnianie dostępu do zbiorów (w tym do zasobów elektronicznych). Gromadzenie zbiorów tradycyjnych powinno odbywać się przy udziale pracowników naukowych i dydaktycznych uczelni. We wszystkich wywiadach dyrektorzy wskazywali na różne sposoby współpracy przy doborze materiałów bibliotecznych. W Bibliotece Akademii Sztuk Pięknych w Łodzi dominujące było składanie dezyderatów, bardzo istotny był także kontakt osobisty z pracownikami - co wynika ze specyfiki małej uczelni. Z jednej strony pracownicy ASP zgłaszali zapotrzebowanie (także $\mathrm{w}$ przekazie ustnym podczas wizyt $\mathrm{w}$ bibliotece), $\mathrm{z}$ drugiej strony bibliotekarze wysyłali kadrze propozycje pozycji do zakupu, które następnie były weryfikowane. Co ciekawe w BASP tradycyjne zbiory biblioteczne, w tym czasopisma prenumerowane, cieszyły się niezmienną popularnością i nadal stanowią trzon kolekcji. Zbiory elektroniczne wykorzystywało się w znacznie mniejszym stopniu, zatem polityka gromadzenia biblioteki była nastawiona na zakup źródeł papierowych.

W pozostałych bibliotekach pojawiały się problemy w komunikacji pomiędzy biblioteką a wydziałami uczelni. Nie zawsze kadra naukowa uczelni była zainteresowana współpracą w tym zakresie. Często pracownicy naukowi nie zdawali sobie sprawy, że biblioteka realizuje zamówienia składane nie tylko przez jednostki uczelniane, ale także przez samych pracowników. W Bibliotece Uniwersytetu Łódzkiego podjęto próby zacieśnienia współpracy z wydziałami UŁ. Przez dwa lata pracownicy Oddziału Gromadzenia i Uzupełniania Zbiorów realizowali politykę aktywizowania kadry naukowej oraz poszerzania zakresu jej kontaktów z biblioteką. Regularnie wysyła się informacje mailowe z prośbami o przesłanie dezyderatów albo weryfikację oferty przygotowanej przez dostawców BUŁ. Praktyka ta została zastosowana przede wszystkim przy zakupach książek zagranicznych, ponieważ biblioteka otrzymuje egzemplarz obowiązkowy i z tego powodu oferta piśmiennictwa w języku ojczystym jest bardzo szeroka. Kadra naukowa mogła wpływać na decyzje o zakupieniu większej liczby egzemplarzy konkretnych tytułów. W komunikacji znaczącą rolę pełniły biblioteki zakładowe, będące naturalnymi łącznikami i pośrednikami pomiędzy jednostkami uczelni, a biblioteką główną. Piestrzyński wskazał także na ważną rolę wymiany międzybibliotecznej, w szczególności zagranicznej. BUŁ podjęła współpracę z 113 jednostkami akademickimi z innych krajów, którym wysyła się publikacje Wydawnictwa UŁ oraz Łódzkiego Towarzystwa Naukowego. 
Odrębne zagadnienie to dobór zasobów elektronicznych i organizacja dostępu do nich. Badane biblioteki (z wyjątkiem BASP) rozbudowały ofertę e-zbiorów i korzystały z Wirtualnej Biblioteki Nauki, stanowiącej stały trzon kolekcji cyfrowych. Został odnotowany wzrost zainteresowania zasobami elektronicznymi przy jednoczesnym spadku wykorzystania źródeł tradycyjnych. Książnice subskrybowały dostępy do konkretnych baz naukowych przydatnych $\mathrm{z}$ punktu widzenia dziedzin reprezentowanych na uczelni. W przypadku zasobów sieciowych zajmowanie się zakupem oraz późniejszym zarządzaniem nabytymi e-zbiorami powierzono specjalnie powołanym do tego jednostkom organizacyjnym. $Z$ rozmów wynikało, że w Bibliotece Politechniki Łódzkiej zajmował się tym Oddział Zbiorów Elektronicznych, w Bibliotece Uniwersytetu Łódzkiego - Samodzielna Sekcja Bibliografii, Bibliometrii i Sieciowych Zasobów Informacji, a w Bibliotece Uniwersytetu Medycznego Sekcja Bibliografii i Baz Danych działająca w Oddziale Informacji Naukowej. W BG UMED inicjatorami zakupu i decydentami byli bibliotekarze - Kozakiewicz zauważył, że współpraca z kadrą naukową w tym zakresie była znikoma. BUŁ organizowała dostęp do e-zasobów z aktywnym udziałem 6 wydziałów (z 12). Jednostki uniwersyteckie występowały tu jako podmioty nie tylko zgłaszające zapotrzebowanie, ale także w kilku przypadkach współfinansujące zakup licencji. Piestrzyński podkreślał, że inicjatorem takiej współpracy była Biblioteka. W BPŁ doborem zajmowali się bibliotekarze. Przy kształtowaniu oferty pracownicy BPŁ sugerowali się zakupami innych bibliotek o zbliżonym profilu działalności oraz rekomendacjami, które otrzymywali od kadry naukowej po testach konkretnych baz (rekomendacje po testach uzyskuje około $20-30 \%$ baz).

Ciekawe zagadnienie poruszył podczas wywiadu Feret. Dyrektor BPŁ dostrzegł zagrożenie polegające na braku polityki wyjścia z prenumeraty bardzo drogich zasobów sieciowych przy jednoczesnym spadku środków finansowych. Feret podkreślał, że rezygnacja z przedłużenia licencji na korzystanie $\mathrm{z}$ baz jest bardzo trudna, ponieważ nie istnieją miarodajne dane, na podstawie których można byłoby podjąć takie decyzje. Sprawdza się, ile razy dany plik został pobrany, zlicza się liczbę odwiedzin. Nie ma natomiast narzędzi, które w sposób pełny wykazałyby czy dany zasób ma wpływ na pracę kadry naukowej uczelni.

W zakresie gromadzenia warto wyróżnić działalność bibliotek związaną $\mathrm{z}$ tworzeniem bibliografii prac powstających w uczelni. Zbieranie, opracowywanie i udostępnianie dorobku naukowego uczelni stanowi istotny wkład w zwiększanie dostępności i widoczności wyników badań naukowych i informacji o nich. Wszystkie badane instytucje podejmowały działania w tym zakresie. W BASP funkcjonował system Expertus - do 2014 r. baza bibliograficzna tworzona była na bieżąco, a ze względu na specyfikę uczelni zawierała głównie wycinki z prasy (informacje o wernisażach, nagrodach za prace artystyczne i temu podobne). W $2015 \mathrm{r}$. dane zbierano w sposób tradycyjny, a dotychczas uzupełniana baza Expertus zawierała ok. 5000 rekordów. W BG 
$\mathrm{UMED}^{14}, \mathrm{BUŁ}^{15}$ i BPŁ ${ }^{16}$ również tworzone są bazy bibliograficzne. Wszystkie uczelnie korzystały z Expertusa. W BG UMED system działał poprawnie i baza była tworzona przez bibliotekarzy na bieżąco. Pracami zajmowała się Sekcja Bibliometrii działająca w Oddziale Technologii Informatycznych. W BPŁ dane do bazy Expertus wprowadzano zbiorczo 2 razy w roku. Podczas wywiadu dowiedziano się, że na Politechnice Łódzkiej trwały prace nad powstaniem zintegrowanego systemu informacji uczelnianej, którego zadaniem jest scalanie rozproszonych danych (informacje o pracownikach, grantach, zespołach badawczych, patentach, dorobku piśmienniczym i temu podobnych). W związku z trwającym okresem przejściowym biblioteka wstrzymała prace w Expertusie. Wyzwaniem stojącym przed instytucją jest importowanie zebranych dotychczas danych - tak do nowego systemu uczelnianego, jak i do PBN (w związku z nałożonym na uczelnie obowiązkiem). W BUŁ trwały prace nad pełnym wdrożeniem Expertusa na uczelni. Rekordy bibliograficzne wprowadzano na bieżąco - system był rozproszony, a dane zdobywano w dwojaki sposób: od wytypowanych pracowników jednostek uczelnianych, od pracowników Bibliotek Zakładowych. Bazie brakowało kompletności, do której dąży BUŁ, a doprowadzenie jej do stanu zadowalającego zapowiadano jako długi proces, wymagający zaangażowania nie tylko ze strony bibliotekarzy.

Biblioteki realizują również zadania związane $\mathrm{z}$ archiwizowaniem dorobku nukowego i dydaktycznego pracowników uczelni. Bort-Nowak podkreśliła, że w BASP proces ten jest o tyle ciekawy, że obiektami często są dzieła artystyczne o bardzo różnym charakterze (na przykład rzeźby, malarstwo, kolekcje butów, mebli). Zrealizowany w latach 2007-2013 przez ASP projekt zaowocował powstaniem Centrum Promocji Mody (CPM). BASP współpracuje stale z CPM posiadającym nowoczesną pracownię digitalizacyjną, której celem jest tworzenie cyfrowych obiektów 3D - skanowaniu poddaje się prace powstałe na uczelni. W czasie badania projekt digitalizacji zasobów dopiero się rozpoczynał. Dyrektor BASP zapowiedziała, że jego efekty będą widoczne dopiero w przyszłości. BUŁ zarządzała Repozytorium Uniwersytetu Łódzkiego (RUŁ), które powstało z inicjatywy Biblioteki w 2011 r. jako platforma udostępniająca otwarte zasoby naukowe i edukacyjne. RUŁ stanowiło największe repozytorium instytucjonalne $\mathrm{w}$ regionie łódzkim. Na platformie gromadzi się materiały dydaktyczne oraz bieżący dorobek naukowy pracowników Uniwersytetu Łódzkiego ze wszystkich dziedzin reprezentowanych na uczelni. Ważny zbiór to kolekcje czasopism naukowych wydawanych na uczelni. W RUŁ zdeponowano już blisko 9000 obiektów (stan na 30 czerwca 2015). BPŁ również archiwizowała dorobek pracowników uczelni. Trwały prace nad

\footnotetext{
${ }^{14}$ Uniwersytet Medyczny w Łodzi, Bibliografia Publikacji Pracowników Uniwersytetu Medycznego w Lodzi, [dostęp 1.07.2015], http://bg.umed.lodz.pl/pl/um.

${ }^{15}$ Biblioteka Uniwersytetu Łódzkiego, Bibliografia i Bibliometria, [dostęp 1.07.2015], http://bul.uni.lodz.pl/?idx=nauka\#\#ibl.

${ }^{16}$ Biblioteka Politechniki Łódzkiej, Baza BIBLIO, bibliografia dorobku piśmienniczego pracowników Politechniki Łódzkiej, [dostęp 1.07.205], http://bg.p.lodz.pl/biblio.
} 
wdrożeniem repozytorium w systemie DSpace, które miałoby stanowić element tworzonego systemu informacji uczelnianej, o którym wspomniano wyżej. BG UMED planowała otwarcie repozytorium w przyszłości.

Wszystkie biblioteki realizowały również usługi w zakresie wyszukiwania wiarygodnych źródeł informacji dla naukowców, w tym tworzenie zestawień tematycznych i bibliografii przedmiotowych. Prace te wykonywali pracownicy różnych jednostek organizacyjnych w ramach obowiązków służbowych. Powstające listy publikacji zawierały dane bibliograficzne nie tylko prac dostępnych w bibliotece, ale także innych, odnotowanych w przeszukiwanych katalogach i bazach bibliograficznych. Swoim zasięgiem czasowym i terytorialnym odpowiadały potrzebom zgłaszającego zapotrzebowanie naukowca. Język poszukiwanych publikacji również ustalano przed rozpoczęciem prac wyszukiwawczych.

Pracownicy BPŁ, BUŁ oraz BG UMED przygotowywali spisy publikacji konkretnych autorów i raporty cytowań - dla poszczególnych pracowników lub na zlecenie jednostek uczelni. Feret podkreślał, że corocznie wysyłane spisy publikacji pracowników naukowych uczelni, dostarczane władzom wydziałów, to dobra praktyka, którą BPŁ stosuje od lat, pomimo braku zarządzeń do tego ją zobowiązujących.

\section{Nowe role pełnione przez lódzkie biblioteki akademickie}

Piestrzyński podkreślił, że zmiany były bardzo widoczne, a biblioteki akademickie przejmują rolę łączników pomiędzy różnymi typami uczestników procesu komunikacji naukowej. Biblioteki zobligowano do wspierania naukowców na każdym etapie ich pracy, zarówno naukowej, jak i dydaktycznej. Stąd zmiany zachodzące $w$ tych procesach oddziałują na biblioteki akademickie, które muszą dostosowywać swoją ofertę do aktualnych potrzeb środowiska.

Rolą, którą biblioteki akademickie zaczęły pełnić i której nasilenie można zaobserwować w skali ogólnopolskiej, jest wspieranie i popularyzacja idei Open Access (OA). Polska jest jednym z krajów, które aktywnie biorą udział w tworzeniu i promowaniu otwartych zasobów. W bazie Directory of Open Access Journals Polska zajmuje 12 miejsce na świecie pod względem liczby otwartych czasopism naukowych. Zainteresowanie tematyką OA przejawia się nie tylko we współtworzeniu zasobów (na przykład repozytoria), ale także w podejmowaniu działań popularyzacyjnych.

Biblioteka Uniwersytetu Łódzkiego od 2009 r. co roku organizowała Seminarium Open Access z okazji międzynarodowych obchodów Open Access Week (Tydzień OA). Spotkania tego cyklu miały charakter otwarty, a ich celem było propagowanie dobrych praktyk $\mathrm{w}$ tworzeniu i wykorzystywaniu zasobów otwartych. Zapraszani goście z całej Polski prezentowali swoje doświadczenia związane $\mathrm{z}$ otwieraniem nauki. Tematyka spotkań co roku była dobierana tak, aby pasowała do ogłaszanego wcześniej ogólnoświatowego 
hasła. W roku 2014 r. było to „Generation Open” i podczas trwania Tygodnia OA w BUŁ można było opowiedzieć się za otwartą nauką dołączając do pokolenia otwartego. Powstała w ten sposób galeria zdjęć osób, które poparły OA.

Warto zauważyć, że biblioteki akademickie są coraz bardziej zainteresowane promocją swojej działalności i zbiorów. Według Fereta rola promocji jest bardzo istotna, jeśli nie najważniejsza w obecnych warunkach funkcjonowania biblioteki. Każda z badanych książnic posiadała stronę internetową (BASP posiadała zakładkę na stronie WWW uczelni, pozostałe serwisy były samodzielne), a także prowadziła działalność popularyzatorską za pośrednictwem poczty elektronicznej. Wiadomości e-mail wysyła się bezpośrednio na adresy służbowe pracowników uczelni. BPŁ oraz BUŁ miały również swoje profile w mediach społecznościowych. Obie biblioteki powołały odrębne jednostki zajmujące się promocją: BPŁ - Dział Promocji i Informacji, BUŁ - Sekcję Promocji, działającą w Oddziale Informacji Naukowej i Prac Naukowo-Dydaktycznych. Sekcja Promocji BUŁ wysyłała również informacje w Newsletterze BUŁ oraz w Biuletynie UŁ, które docierały do zapisanych odbiorców raz w tygodniu. Ważnym aspektem działalności Sekcji było również utrzymywanie dobrych relacji z mediami i promowanie działalności biblioteki w mediach lokalnych i krajowych.

Postulowane w literaturze przedmiotu większe wspieranie samego procesu publikowania prac naukowych, jako nowa rola, którą biblioteki również powinny pełnić, było w łódzkich książnicach realizowane w niewielkim zakresie. BASP podjęła się wspierania procesu wydawniczego na uczelni - Biblioteka była odpowiedzialna za nadawanie nr ISBN publikacjom oraz za rozesłanie egzemplarza obowiązkowego. W BPŁ sytuacja się zmieniała, ponieważ od 2014 roku Wydawnictwa Uczelniane PŁ oraz Księgarnia i sklep online zostały włączone do struktury organizacyjnej Biblioteki. Trwał okres przejściowy, w którym BPŁ przejmowała nowe zadania. W pozostałych bibliotekach działania związane ze wspieraniem procesu publikowania prac naukowych były incydentalne. Przypadki te wynikały ze stałej współpracy z konkretnymi pracownikami naukowymi uczelni, a sytuacje takie nie były w żaden sposób ustrukturalizowane i zachodziły $\mathrm{w}$ związku $\mathrm{z}$ utrzymywaniem relacji zawodowych pomiędzy pracownikami. Doradztwo realizowane przez bibliotekarzy w opisywanym zakresie dotyczyło głównie prawnych aspektów publikowania, wskazywania czasopism, które mogą być interesujące z punktu widzenia naukowca, czy pozytywnych efektów przyjęcia otwartego modelu publikowania.

Szerzej realizowana była natomiast rola edukacyjna bibliotek. Wszystkie (poza BASP) badane książnice posiadały ofertę z zakresu edukacji informacyjnej, skierowaną do pracowników naukowych uczelni. Szkolenia realizowane były w dwojaki sposób. Bibliotekarze prowadzili zajęcia samodzielnie, przygotowywali scenariusze i realizowali konkretne tematy na spotkaniach w bibliotece lub na wydziałach. Drugim sposobem było organizowanie szkoleń ze specjalistami, w tym przedstawicielami dostawców naukowych baz danych czy systemów wyszukiwawczych. W takim wypadku biblioteki pełniły rolę 
pośrednika i organizatora, zapraszając zewnętrznego trenera i zapewniając odpowiednie warunki do przeprowadzenia szkolenia. BG UMED poza tradycyjnymi formami oferowała kursy online osadzone na platformie e-learningowej, stworzone specjalnie dla kadry naukowej uczelni. Tematyka proponowanych przez badane biblioteki akademickie szkoleń była szeroka i obejmowała między innymi techniki wyszukiwawcze, szkolenia instruktażowe związane z wykorzystywaniem konkretnych baz czy narzędzi, szkolenia z zakresu prawa autorskiego, szkolenia dotyczące metod zwiększania widoczności dorobku naukowego i cytowań.

Biblioteki akademickie pełnią zatem rolę edukacyjną i doradczą, coraz częściej włączają się też w tworzenie standardów, wytycznych, rekomendacji, a nawet nowych narzędzi dla kadry naukowej. Przykładem może być udział pracowników i władz bibliotek w pracach różnego typu zespołów i gremiów na uczelniach oraz w kraju. Największy wpływ na kształtowanie nowych standardów i wytycznych mieli dyrektorzy placówek, którzy reprezentowali swoje instytucje i podejmowali decyzje strategiczne. Warto wspomnieć o członkostwie BUŁ w Koalicji Otwartej Edukacji i udziale pracowników BUŁ w pracach zespołu Otwarty Uniwersytet, który powstał na uczelni. Wartość repozytorium UŁ podniosło zarządzenie Rektora $\mathrm{UL}^{17}$ regulujące obowiązek publikowania doktoratów przed obroną w Repozytorium UŁ, opracowane wspólnie przez przedstawicieli Biblioteki i Biuro Rektora. Na mocy tego dokumentu do zasobów RUŁ w ciągu pół roku trafiło blisko 80 prac doktorskich (stan na czerwiec 2015 r.).

\section{Zakończenie}

Biblioteki akademickie biorą aktywny udział w procesie komunikacji naukowej. Środowisko naukowe uczelni jest jedną z ważniejszych grup odbiorców, a realizowanie zadań mających na celu wsparcie tej grupy (na każdym etapie pracy), to istotna rola współczesnej książnicy akademickiej. Dyrektorzy wszystkich badanych bibliotek zgadzają się, że instytucje przez nich zarządzane pełnią głównie funkcje pomocnicze, usługowe. Piestrzyński podczas wywiadu podsumował wspieranie procesu komunikacji naukowej. Według Dyrektora BUŁ biblioteki akademickie prowadziły działalność na wielu płaszczyznach, takich jak:

- gromadzenie i organizowanie dostępu do nowości wydawniczych, do światowego piśmiennictwa naukowego z zakresu dziedzin reprezentowanych na uczelniach (polityka gromadzenia podporządkowana potrzebom pracowników uczelni), w tym organizowanie dostępu do naukowych baz danych;

\footnotetext{
${ }^{17}$ Zarzadzenie nr 23 Rektora Uniwersytetu tódzkiego z dnia 16.12.2015 r. w sprawie: gromadzenia i udostępniania przez Bibliotekę Uniwersytetu Lódzkiego rozpraw doktorskich dopuszczonych do publicznej obrony w Uniwersytecie Łódzkim, [dostęp: 1.07.2015], http://repozytorium.uni.lodz.pl:8080/RepoInfo/docs/zarzadzenie_Rektora_nr_23.pdf .
} 
- $\quad$ wspieranie procesu wyszukiwania wiarygodnych źródeł naukowych;

- informowanie i doradztwo na temat nowych możliwości popularyzowania wyników naukowych, zwiększania widoczności publikacji w sieci i cytowalności, nowych narzędzi dla naukowców;

- świadczenie usług szkoleniowych $\mathrm{z}$ zakresu edukacji informacyjnej, w tym obsługi naukowych baz danych czy narzędzi wspomagających proces wyszukiwania źródeł, organizowania bibliografii, autoarchiwizacji własnego dorobku;

- $\quad$ ułatwianie komunikacji i wymiany doświadczeń pomiędzy jednostkami akademickimi w kraju i zagranicą poprzez organizację konferencji, seminariów, warsztatów;

- $\quad$ tworzenie lub adaptowanie nowych narzędzi dla potrzeb komunikacji naukowej, jak na przykład tworzenie repozytorium czy baz bibliograficznych;

- $\quad$ promowanie idei Open Access i Open Science, promowanie stosowania nowych technologii w komunikacji naukowej;

- $\quad$ rekomendowanie dobrych praktyk, wpływanie na politykę uczelni, na przykład poprzez współtworzenie dokumentów wewnętrznych regulujących niektóre aspekty publikowania, gromadzenia czy udostępniania dorobku naukowego uczelni.

To, które funkcje są realizowane i w jakim stopniu biblioteka je pełni, w dużej mierze zależy od władz biblioteki oraz władz samej instytucji macierzystej. Książnice w Łodzi realizowały opisane w artykule zadania tradycyjne i nietradycyjne w różnym zakresie, w zależności od uczelni, w której funkcjonują. Ważne jest to, że biblioteki zauważają potrzeby środowiska akademickiego i biorą je pod uwagę kształtując swoją ofertę, choć jeszcze nie wszystkie działania przynoszą oczekiwane efekty. Biblioteki akademickie podejmują się nowych wyzwań i poszukują dobrych rozwiązań, redefiniują swoją rolę w komunikacji naukowej, przystosowują się do funkcjonowania w szybko zmieniającej się rzeczywistości - wykorzystują nowe szanse szanując jednocześnie swoje tradycje.

\section{Bibliografia}

Barjak F., The Role of the Internet in Informal Scholarly Communication, „Journal of the American Society for Information Science and Technology" 2006, nr 57 (10), s. $1350-1367$.

Bednarek-Michalska B., Modele biznesowe otwartego publikowania naukowego: informator dla polskich wydawców uczelnianych, Torun 2013.

Bendyk E., Przewodnik po otwartej nauce, Warszawa 2009.

Baza BIBLIO, bibliografia dorobku piśmienniczego pracowników Politechniki Łódzkiej, [dostęp 1.07.2015], http://bg.p.lodz.pl/biblio.

Bibliografia Publikacji Pracowników Uniwersytetu Medycznego w Łodzi, [dostęp 1.07.2015], http://bg.umed.lodz.pl/pl/um.

Biblioteka Uniwersytetu Łódzkiego, Bibliografia i Bibliometria, [dostęp 1.07.2015], http:// bul.uni.lodz.pl/?idx=nauka\#bibl. 
Branin J.J., Case, M., Reforming Scholarly Publishing in the Sciences: A Librarian Perspective, „Notices of the AMS”, 1998, nr 45 (4), s. 475-86.

Carpenter M., Graybill, J., Offord Jr J., Piorun, M., Envisioning the Library's Role in Scholarly Communication in the Year 2025, „Portal: Libraries and the Academy” 2011, nr 11 (2), s. 659-81.

Delaney G., Bates J., Envisioning the Academic Library: A Reflection on Roles, Relevancy and Relationships, „New Review of Academic Librarianship”, 2014, [dostęp: 1.07.2015], http://dx.doi.org/10.1080/13614533.2014.911194.

Egghe L., The Hirsch Index and Related Impact Measures, „Annual Review of Information Science and Technology", 2010, nr 44 (1), s. 65-114.

Feret B., Library as a Hub. Changing Roles and Functions of Academic Library, [w:] Open Libraries, Open Resources, Open to Change?, West Lafayette 2011, [dostęp 1.07.2015], http://docs.lib.purdue.edu/cgi/viewcontent.cgi?article=1941\&context=iatul.

Gelfand J., Palmer C., Weaving Scholarly Communication and Information Literacy: Strategies for Incorporating Both Threads in Academic Library Outreach, [w:] Common Ground at the Nexus of Information Literacy and Scholarly Communication, Chicago 2013, s. 1-24, [dostęp: 1.07.2015], http://www.ala.org/acrl/sites/ala.org.acrl/files/content/ publications/booksanddigitalresources/digital/commonground_oa.pdf.

Guthrie K., Housewright R., Repackaging the Library: What Do Faculty Think?, ,Journal of Library Administration” 2010, nr 51 (1): 77-104.

Hołdys A., Harvard Buntuje Naukowców, „Gazeta Wyborcza”, 2012, [dostęp: 1.07.2015], http://wyborcza.pl/1,75476,11736662,Harvard_buntuje_naukowcow.html.

Johnston M., Changing the Paradigm: The Role of Self-Archiving and Institutional Repositories in Facilitating Global Open Access to Knowledge, „Access to Knowledge: A Course Journal", $2010 \mathrm{nr} 2$ (1), [dostęp 1.07.2015], http://ojs.stanford.edu/ojs/index.php/a2k/article/ view/429.

Kozierski P. [et al.], Open Access analiza zjawiska z punktu widzenia polskiego naukowca. Poznań, Kraków 2013.

Kulczycki E., Blogi i serwisy naukowe. Komunikacja naukowa w kulturze konwergencji, 2006, [dostęp: 1.07.2015], https://www.repozytorium.amu.edu.pl/jspui/handle/10593/2520.

Maron N. L., Kirby Smith K., Current Models of Digital Scholarly Communication: Results of an Investigation Conducted by Ithaka for the Association of Research Libraries, Washington 2008, [dostęp 1.07.2015], http://www.arl.org/storage/documents/publications/ digital-sc-models-report-2008.pdf.

Piwowar H., Altmetrics: Value All Research Products, „Nature” 2013, nr 493 (7431), s. 159159.

Sample I., Harvard University Says It Can't Afford Journal Publishers Prices, „The Guardian” 2012, nr 24, [dostęp: 1.07.2015], http://wyborcza.pl/1,75476,11736662,Harvard_buntuje_ naukowcow.html.

Shulenburger D. E., Scholarly Communications Is Not Toxic Waste: Lessons Learned, 2004, [dostęp: 1.07.2015], http://kuscholarworks.ku.edu/dspace/handle/1808/58.

Thomas W. J., The Structure of Scholarly Communications within Academic Libraries, , Serials Review" $2013 \mathrm{nr} 39$ (3), s. 167-71.

Ustawa z dnia 27 czerwca 1997 r. o bibliotekach, „Dziennik Ustaw” 1997, nr 85, poz. 539 , art. 4.

Zarządzenie nr 23 Rektora Uniwersytetu tódzkiego z dnia 16.12.2015 r. w sprawie: gromadzenia i udostępniania przez Bibliotekę Uniwersytetu Łódzkiego rozpraw doktorskich dopuszczonych do publicznej obrony w Uniwersytecie Łódzkim, [dostęp: 1.07.2015], http:// repozytorium.uni.lodz.pl:8080/RepoInfo/docs/zarzadzenie_Rektora_nr_23.pdf. 